\title{
Kepercayaan Terhadap Kemampuan Budaya Bengkung dalam Meningkatkan Produksi Air Susu Ibu Pada Masyarakat Bulukumba
}

\author{
Mudyawati Kamaruddin ${ }^{* 1)}$, Andi Deasi Tenri Rawe ${ }^{1)}$, Achriani Asra ${ }^{1)}$, dan Ismail Marzuki ${ }^{2)}$ \\ ${ }^{1)}$ Akademi Kebidanan Tahirah Al Baeti Bulukumba \\ ${ }^{2)}$ Dosen Universitas Fajar Fakultas Kimia Makassar
}

\begin{abstract}
ABSTRAK
Budaya pemakaian stagen ataupun kain pengikat atau dikenal dengan istilah "bengkung" (Bekkeng dalam bahasa Bugis) setelah melahirkan menurut sebagian masyarakat di Bulukumba dapat membantu meningkatkan produksi Air Susu Ibu (ASI). Hal ini telah dipercaya oleh masyarakat Bulukumba sejak lama hingga turun temurun dijadikan kebiasaan setempat sebagai perawatan pasca melahirkan. Dengan demikian ingin diketahui apakah budaya pemakaian bekung setelah melahirkan dapat meningkatkan produksi ASI atau tidak, sehingga tujuan penelitian ini adalah untuk mengkaji interprestasi masyarakat setempat tentang tujuan pemakaian bekung, dan untuk mengetahui hubungan antara pemakaian bekung dan peningkatan ASI. Metode penelitian dengan metode analitik cross sectional. Metode sampling yang digunakan adalah accidental sampling. Selain budaya bekung yang dijadikan objek penelitian ini, variabel lain seperti faktor makanan, psikis, dan isapan bayi menjadi alat ukur untuk mengetahui perubahan peningkatan ASI. Dengan teknik pengambilan data yaitu melalui interview dan lembar tes yang dibagikan pada ibu nifas. Hasil yang diperoleh menunjukkan bengkung yang digunakan dapat meningkatkan hormon dalam tubuh ibu nifas, sehingga tidak secara langsung juga merangsang produksi ASI selama masa nifas
\end{abstract}

Kata kunci : Budaya Bengkung, ASI, Hormon, ibu nifas, Bulukumba.

\section{PENDAHULUAN}

Kebudayaan merupakan suatu kebiasaan, yang dilakukan secara turun temurun dan dapat memberikan stimulasi ke masyarakat dalam memelihara dan menjaga kesehatan (Tjong, 2012). Salah satunya adalah kebiasaan menggunakan bengkung, yang dalam bahasa Bugisnya dikenal sebagai bekkeng. Walau budaya bekkeng ini masih menjadi pro dan kontra bagi praktisi kesehatan, sebagian masyarakat di Indonesia masih mempercayai sebagai salah satu cara dalam perawatan ibu setelah melahirkan. Menurut Benjamin (2013) bahwa banyak manfaat dari penggunaan bengkung, diantaranya adalah memaksimalkan involusi uterus, memulihkan tonus abdomen, mengurangi nyeri punggung dan menyangga punggung ibu nifas, sehingga lebih cepat membantu pembentukan postur tubuh. Dengan penggunaan bengkung, tekanan pada perut dapat membantu sebagai penyangga perut pada daerah lumbopelvic dengan adanya pemberian tekanan pada otot transverses abdominis (Benjamin dkk., 2013).

Di beberapa daerah di Bulukumba, masih mempercayai jika penggunaan bekkeng juga dapat memperlancar Air Susu Ibu (ASI). Dari data pendahuluan yang diperoleh terhadap beberapa daerah Bulukumba yang menggunakan bekkeng sebagai cara memperlancar produksi ASI, yaitu desa Bontonyeleng. Desa Bontonyeleng ini berada di kecamatan Gantarang kabupaten Bulukumba. Walau beberapa kondisi gangguan ketidaknyamanan yang dialami ibu nifas saat menggunakan bekkeng, seperti keadaan sesak nafas dan bengkak pada kaki jika penggunaannya terlalu erat dan lama, rasa gatal atau bahkan alergi pada kulit perut jika bekkeng yang digunakan jarang diganti. Akan tetapi, masyarakat di desa Bontonyeleng masih tetap ingin menggunakan bekkeng karena

*1 Korespondensi penulis: Mudyawati Kamaruddin, Telp.089652747379, Email : mudyak706@gmail.com 
kepercayaan terhadap produksi ASI dan perbaikan kondisi perut seperti sediakala saat belum hamil.

Permasalahan yang terjadi di masyarakat Bontonyeleng dimana budaya bekkeng dihubungkan dengan peningkatan produksi ASI menarik peneliti untuk mengkaji apakah kebiasaan menggunakan bekkeng pada ibu nifas dapat menyebabkan ASI dapat lancar?

\section{METODE PENELITIAN}

Tujuan dari penelitian ini adalah secara umum untuk mengetahui budaya bekkeng pada masyarakat Bontonyeleng, sedangkan tujuan khusus yang akan dicapai adalah mengkaji pengetahuan ibu nifas tentang budaya bekkeng dikaitkan dengan produksi ASI. Sasaran penelitian ini adalah ibu nifas yang aktif menggunakan bekkeng sebagai perawatan pasca melahirkan di Desa Bontonyeleng Kecamatan Gantarang Kabupaten Bulukumba.

Penelitian ini diawali dengan mengadakan survei untuk mendata jumlah ibu nifas yang menggunakan bekkeng dan mewawancarai beberapa soalan tentang budaya bekkeng. Berdasarkan pendataan awal tersebut, maka sampel penelitian ini adalah sampel jenuh, yaitu sampelnya adalah semua ibu nifas yang menggunakan bekkeng di desa Bontonyeleng.Hal ini disebabkan populasi pengguna bekkeng kurang dari 100 orang di lokasi penelitian.

Instrumen penelitian yang digunakan adalah kuesioner yang berisi pertanyaan tentang pengetahuan ibu nifas tentang budaya bekkeng, hubungan budaya bekkeng dan peningkatan ASI. Selain itu, kuesioner dilengkapi dengan data tentang karakteristik responden seperti umur, tingkat pendidikan, pekerjaan, paritas dan pemenuhan asupan nutrisi.

\section{HASIL DAN PEMBAHASAN}

Hasil penelitian yang diperoleh dari kegiatan ini adalah:

1. Data ibu nifas berdasarkan umur.

Tabel 1. Tingkat Umur Ibu Nifas

\begin{tabular}{ccc}
\hline Umur responden & Frekuensi(F) & Persentase (\%) \\
\hline 20-24 tahun & 13 & $43,34 \%$ \\
$25-29$ tahun & 9 & $30 \%$ \\
$30-34$ tahun & 4 & $13,33 \%$ \\
35-39 tahun & 4 & $13,33 \%$ \\
\hline Jumlah & 30 & $100 \%$ \\
\hline
\end{tabular}

Berdasarkan tabel di atas diketahui bahwa sebagian besar ibu nifas berusia antara 20 - 24 tahun $(43,34 \%)$.

2. Data ibu nifas berdasarkan pendidikan

Tabel 2. Tingkat Pendidikan Ibu Nifas

\begin{tabular}{lcc}
\hline Tingkat pendidikan & Frekuensi(F) & Persentase(\%) \\
\hline Tidak Sekolah & 3 & $10 \%$ \\
SD & 10 & $33,33 \%$ \\
SMP & 8 & $26,67 \%$ \\
SMA & 8 & $26,67 \%$ \\
Perguruan tinggi & 1 & $3,33 \%$ \\
\hline Jumlah & 30 & $100 \%$ \\
\hline
\end{tabular}

Berdasarkan tabel di atas diketahui bahwa sebagian besar ibu nifas mempunyai tingkat pendidikan Sekolah Dasar (33,33\%).

3. Data ibu nifas berdasarkan pengetahuan tentang bengkung 
Tabel 3. Tingkat Pengetahuan Ibu Nifas

\begin{tabular}{ccc}
\hline Tingkat pengetahuan & Frekuensi (F) & Persentase (\%) \\
\hline Baik & - & - \\
Cukup & - & - \\
Kurang & 30 & $100 \%$ \\
\hline Jumlah & 30 & $100 \%$ \\
\hline
\end{tabular}

Berdasarkan tabel 4 di atas tingkat pengetahuan ibu nifas tentang bengkung sebagai produksi ASI masih sangat kurang (100\%). Bengkung yang diterjemahkan dalam bahasa Bugis menjadi bekkeng, merupakan kain pembebat yang dililitkan di perut ibu setelah melahirkan berupa kain tenun yng mempunyai lebar $20 \mathrm{~cm}$ dan mempunyai panjang 5 meter dengan warna standar seperti putih, hitam, hijau atau kuning. Cara pemakaian bekkeng adalah dililitkan di pinggang atau perut berkali-kali hingga kain habis. Biasanya wanita setelah melahirkan akan menggunakan kain ini karena diyakini bisa membantu dalam pembentukan perut dan pinggan menjadi langsing kembali (Ernawati dan Hudiyanti, 2013).

Beberapa manfaat bekkeng yaitu dapat memaksimalkan involusi uterus, memulihkan tonus abdomen, mengurangi nyeri dan menyangga punggung ibu nifas sehingga membantu pembentukan postur tubuh menjadi lebih cepat terbentuk (Amalia, 2014). Tubuh terutama bagian perut, bisa mendapatkan tekanan pada perut sehingga membantu menyangga perut dan daerah lumbopelvic dengan memberikan sedikit tekanan di otot tranversus abdominis (Benjamin dan peins, 2013) sehingga dapat membantu otot abdomen bekerja lebih sempurna. Penggunaan bekkeng yang disertai dengan latihan fisik yang teratur akan mengurangi insiden nyeri punggung bagian bawah pada ibu nifas (Motolla, 2012).

Di masyarakat Bulukumba, keberadaan bekkeng sudah menyatu dengan kehidupan budaya masyarakat sebagai perawatan pada perut pasca persalinan. Akan tetapi, sebagian masyarakat Bulukumba terutama yang tinggal di desa Bontonyeleng percaya budaya menggunakan bekkeng dapat membantu dalam memproduksi ASI selain memperbaiki bentuk tubuh setelah melahirkan. Walau secara teori bekkeng tidak mempunyai hubungan dengan produksi ASI, hal ini dilihat dari hasil pengetahuan ibu nifas sebagai responden dalam penelitian ini tentang fungsi bekkeng terhadap produksi ASI, akan tetapi penggunaan bekkeng kemungkinan memberikan tekanan yang terus menerus pada daerah sekitar perut yang dapat mengaktifkan beberapa hormon. Diketahui produksi ASI sangat dipengaruhi oleh hormonal seperti prolaktin dan oksitosin. Selain itu, produksi ASI sangat ditentukan oleh salah satunya adalah prinsip supply and demand, artinya semakin sering payudara diisap dan dikosongkan maka semakin banyak ASI yang akan diproduksi. Sedangkan kendala yang biasa ditemukan pada masyarakat adalah kurangnya produksi ASI disebabkan kurang maksimalnya bayi mengisap ASI dikarenakan puting susu terbenam, dan puting susu datar (Kusumaningrum, 2016 dan Soetjiningsih, 2013).

Apabila dihubungkan dengan fungsi perawatan ibu nifas pasca persalinan dengan menggunakan bekkeng terhadap produksi ASI, kemungkinan penekanan yang terjadi pada otot tranversus abdominis terus menerus saat menggunakan bekkeng, akan memberikan dan membantu puting ibu nifas yang sebelumnya terbenam atau kondisi puting susu yang datar akan menjadi normal, sehingga bayi akan mudah menghisapnya dan produksi ASI terangsang. Kemungkinan lain, dengan pemakaian bekkeng pada ibu nifas yang memberikan penekanan pada daerah perut secara rutin dan dibantu dengan olah raga fisik secara teratur, akan mengaktifkan hormon-hormon yang bertugas dalam produksi ASI.

\section{KESIMPULAN}

1. Berdasarkan survei terhadap pemakaian bekkeng di Desa Bontonyeleng, hampir semua ibu nifas memiliki pengetahuan yang kurang terhadap funsgi bekkeng dalam membantu produksi ASI. Penggunaan bekkeng hanyalah digunakan sebagai 
budaya turun temurun di desa Bontonyeleng tanpa memahami dan mengetahui fungsi bekkeng sebenarnya.

2. Saran yang diperlukan untuk meningkatkan dan memfungsikan penggunaan bekkeng sebagai budaya di Masyarakat, sebaiknya dilakukan penyuluhan yang disertai dengan praktik menggunakan bekkeng yang baik dan benar.

\section{DAFTAR PUSTAKA}

Amalia, A. 2014. Nyeri Pasca Bersalin. Majalah Ayah Bunda. Terbit bulan Desember 2014.

Benjamin, W dan Peins, L.L., 2013. Systematic Review : Effect of Exercise on Diastasis of The Rectus Abdomini Muscle in The Antenatal and Postnatal Period, Journal of Physiotherapy 722. www. ncbi.nlm,nih.gov.

Ernawati, D.W. dan Hudiyawati. 2013. Hubungan Penggunaan Stagen Terhadap Diastatis Rectus Abdominis Di Rumah Bersalin Hasanah Gemolong Sragen. Fakultas Ilmu Kesehatan. Universitas Muhammadiyah Surakarta.

Kusumaningrum, A.T. 2016. Hubungan Dukungan Keluarga Dengan Pengeluaran ASI Pada Ibu Post Partum Hari Ke-3 Di RSUD DR. Soegiri Lamongan. Program Studi D3 Kebidanan STIKES Muhammadiyah Lamongan.

Soetjiningsih. 2013. ASI Petunjuk untuk Tenaga Kesehatan. Jakarta: EGC.

Sugiyono. 2014. Metode Penelitian Kualitatif Kuantitatif \& RND. Bandung: Alfabeta

Tjong, J.J., 2012. Bunda yang melahirkan, Perlukah Pakai Gurita? www.ibuhamil.comresswell, J.W.,1998. Qualitative inquiry and research design: Choosing among five traditions. Thousand Oaks, CA: Sage.

\section{UCAPAN TERIMA KASIH}

Ucapan terima kasih penulis sampaikan kepada yang berkontribusi pada penelitian ini, yaitu Puskesmas Bontonyeleng, Mahasiswa yang telah membantu dalam menyebarkan kuesioner dan mendapatkan informasi tentang ibu nifas yang menggunakan bekkeng, para ibu nifas dan keluarganya, serta semua pihak yang telah membantu kegiatan penelitian ini hingga penulisan laporan selesai. 